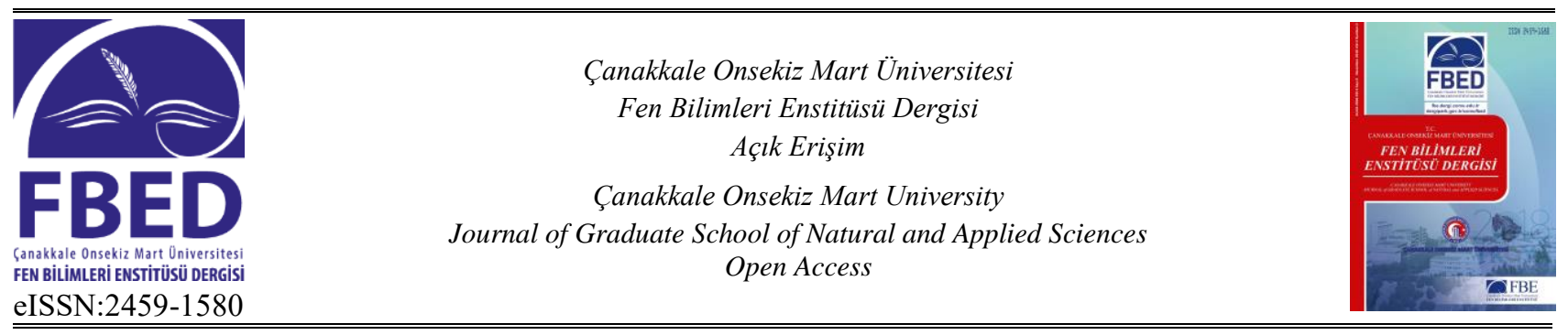

eISSN:2459-1580

\title{
Sürdürülebilir Afet Lojistiğine Yönelik İdeal Afet Depo Yeri Seçimi: Giresun İli Örneği
}

\author{
Mustafa Ergün $^{1 *}$, Selçuk Korucuk ${ }^{1}$, Salih Memiş ${ }^{1}$ \\ ${ }^{1}$ Giresun Üniversitesi Bulancak KK UBYO, Uluslararası Lojistik ve Taşımacılık Böl, Bulancak, 28300, Giresun
}

$\begin{array}{ll}\text { Makale Tarihçesi } \\ \text { Gönderim: } & 07.02 .2020 \\ \text { Kabul: } & 20.04 .2020 \\ \text { Yayım: } & 22.05 .2020\end{array}$

Araștırma Makalesi

\begin{abstract}
Öz - Meydana gelen felaketler çoğunlukla öngörülemez ama her an oluşabileceği varsayılarak önlem almak gerekmektedir. Afet durumunda ihtiyaç duyulan malzemelerin temin edilmesi ve gerekli müdahalelerin yapılması, afete maruz kalan kimselerin hayatta kalmasına doğrudan etki eden çok önemli uygulamalardır. Özellikle gerekli olan malzemenin doğru ve süratli bir biçimde yerine ulaştırılması, ideal afet depo yeri seçimi bileşenlerinin dikkatli bir biçimde incelenmesi ve analiz edilmesine bağlıdır. Depo yerlerinin yanlış belirlenmesi demek, afet bölgesine yardım gönderilememesi veya gönderilen yardımların doğru yere ulaşmaması anlamına gelmektedir. Bu durum yapılan bütün uğraşların boşa gitmesi ve afetzedelerin gerekli yardımları alamamalarıyla sonuçlanabilir. Bu çalışmada, sürdürülebilir afet lojistiğine yönelik Giresun'da ideal afet depo yeri seçimi ölçütleri değerlendirilmiş ve ideal afet depo yeri seçimi yapılmıştır. Bu amaçla sürdürülebilir ideal afet depo yeri seçimi alternatiflerinin belirleyicisi olan ölçütlerin ağırlıklandırılması, AHS (Analitik Hiyerarși Süreci) yöntemi ile yapılmıștır. Daha sonra, AHS temelli MAUT (Multi Attribute Utility Theory-Çok Nitelikli Karar Verme) ve SAW (Simple Additive Weighting-Basit Toplamlı Ağırlıklandırma) yöntemleriyle ideal afet depo yeri seçimi gerçekleştirilmiştir. Yapılan değerlendirme sonucunda ideal afet depo yeri seçimi ölçütlerinin en önemlisi "Altyapı" olmuştur. En önemli alt ölçütün ise "Afetsellik Yapısı" olduğu görülmüştür. Öte yandan hem MAUT hem de SAW yöntemleri ile elde edilen sonuçlara göre sürdürülebilir ideal afet depo yerinin " $\mathrm{A}_{2}$ " olduğu saptanmıştır.
\end{abstract}

\section{Optimum Disaster Warehouse Location Selection for Sustainable Di- saster Logistics: Case of Giresun Province}

${ }^{1}$ Giresun University Bulancak KK School of Applied Sciences, Department of International Logistics and Transportation, Bulancak, 28300, Giresun

\begin{abstract}
Article History
Received: $\quad 07.02 .2020$

Accepted: $\quad 20.04 .2020$

Published: $\quad 22.05 .2020$
\end{abstract}

Research Article

\begin{abstract}
The disasters that occur are mostly unpredictable, but it is necessary to take precautions, assuming that they may occur at any time. When the disaster occurs, interventions and supply of necessary materials are very important applications which directly affect the survival of the victims. Accurate, dynamic and fast delivery of the necessary material depends on careful examination and analysis of the criteria for optimum disaster warehouse site selection. Incorrect determination of the storage locations means that the aid cannot be sent to the disaster area or the aid sent to the incorrect location. This situation may result in wasted efforts and disaster victims not getting any help. In this study, sustainable disaster logistics criteria were evaluated in the selection of disaster warehouse locations in Giresun and optimum disaster warehouse locations were selected. For this purpose, weighting of the criteria which are the determinants of alternative disaster warehouse site alternatives has been determined by AHP (Analytic Hierarchy Process) method. Then, AHP based MAUT (Multi Attribute Utility Theory) and SAW (Simple Additive Weighting) methods were used to select the optimum disaster warehouse location. As a result of the evaluation, "infrastructure" was the most important criteria for the selection of the optimum disaster warehouse location. The most important sub-criterion was "Disaster Structure". On the other hand, it was determined that the sustainable optimum disaster warehouse location selection was " $\mathrm{A}_{2}$ ", which was obtained by both MAUT and SAW methods.
\end{abstract}

Keywords - Warehouse location selection, Disaster logistics, AHP, MAUT, SAW.

ID http://orcid.org/0000-0003-1675-0802 mustafa.ergun@ giresun.edu.tr

2 (D) http://orcid.org/0000-0003-2471-1950 selcuk.korucuk@ giresun.edu.tr

3 (D) http://orcid.org/0000-0003-1345-3618 salih.memis@ giresun.edu.tr

*Sorumlu Yazar / Corresponding Author

"Bu çalı̧̧ma 7-9 Aralık 2018 tarihinde Erzurum IV. Uluslararası Mesleki ve Teknik Bilimler Kongresinde sunulan bildirinin gözden geçirilmiş, yeniden düzenlenmiş ve genişletilmiş halidir." 


\section{Giriş}

Günümüzde doğal afetler geçmişe nazaran daha fazla insanın ölümüne ve yaralanmasına yol açmakta ve meydana gelen bu durum, felakete maruz kalan ülkelere daha fazla maliyet yüklemektedir (O'Brien vd., 2006). Hızlı bir şekilde artan tüketimle birlikte azalan doğal kaynaklar, ekonomik olarak sürdürülebilirlik çalışmalarının yaygınlaşmasına sebep olmuştur. Sürdürülebilirlik kavramının temelinde; çevre dengesinin bozulmaması, doğal çeşitliliğin korunması ve ekosistemin doğru şekilde çalışması yatmaktadır. Ürünlerin, tedarikçiden nihai tüketiciye kadar uzanan zincir içerisindeki hareketi, lojistik yönetim sisteminin sürdürülebilirlik kavramı için önemini ortaya koymaktadır (Christopher, 2011). Bu açıdan bakıldığında lojistik faaliyetleri de birçok ekonomik faaliyet gibi sürdürülebilirlik kavramının kapsamına girmektedir.

Sürdürülebilirlik, çağımızda toplumların artan bir oranda talep ettiği kurumsal bir tutumdur. Bu bağlamda, lojistik işletmelerine de önemli görevler düşmektedir. Bununla birlikte, sürdürülebilir lojistik sistemlerin tasarımı, planlaması ve işletmesi, şirketler için zor bir süreçtir. Bu tür zorluklara cevap verebilmek için şirketler ekonomik, çevresel ve sosyal hedefleri göz önüne alarak lojistik yapılarını etkin bir şekilde yönetmelidirler (Ramos vd., 2014). Yaşanan bu tür olumsuzluklar sebebiyle lojistik yönetiminde ve daha özellikli olarak afet lojistiğinde sürdürülebilirlik kavramının önemi ortaya çıkmaktadır.

Lojistikte sürdürülebilirlik olgusu doğaya daha az zarar vermekten geçer. Bu durum, depo yeri seçimi yaparken de oldukça önemlidir. Çünkü seçilen yerlerin aynı zamanda doğaya zarar vermeyecek şekilde belirlenmiş olması gerekmektedir. Lojistikte sürdürülebilirlik kavramı, doğayla barışık lojistik uygulamalarını işaret etmektedir. Bu uygulamalar, lojistik operasyonlarda kullanılan fosil yakıtlarına alternatifler olabileceği gibi lojistik depoların yer seçimi yapılırken doğayla uyumlu olmasını da kapsayabilir. Dolayısıyla sürdürülebilir afet lojistiğini, olağanüstü hallerden etkilenen, yardıma gereksinimi olan insanlara yardım edebilmek için, insanların, kaynakların, teknik olanakların ve bilginin toplanmasını içeren ve bunları yaparken de doğaya zarar vermeyecek sistemler ve süreçler geliştiren bir kavram olarak tanımlamak mümkündür (Van Wassenhove, 2006).

Kısa ve uzun vadede, herhangi bir yerde felaketten etkilenen bölgeler ve bu bölgelerde yaşayanlar için ekonomik ve sosyal yıkımlar olabilir. Bazı tehlikeli doğa olayları nispeten küçük ölçekli olsa bile, olay sonrası iyi yönetilmediği takdirde büyük bir felaketle sonuçlanabilir. Bu durum da kısa ve uzun vadede, felaketten etkilenen bölgeler ve sakinleri için yıkıcı sonuçlar doğurabilir (Flanagan vd., 2011). Bununla birlikte felaket yaşanan bölgelere gerekli yardımların ulaştırılması ve bu yardımların depolanması büyük önem arz etmektedir.

Doğal afetler (depremler, su baskınları ve fırtınalar gibi) her y1l farklı ülkelerde büyük can kayıplarına neden olmaktadır. Dünyada meydana gelen afetlerin sayısı her yıl arttıkça, kriz yönetiminin önemi daha fazla ortaya çıkmaktadır. Afet esnasında ortaya çıkan kriz sürecinin doğru yönetilememesi ve planlanamaması daha fazla zararın meydana gelmesine yol açmaktadır. Yardım lojistiği de, kriz yönetiminin dört aşamasından ilk ikisi olan hazırlık ve müdahale faaliyetlerinin yaklaşık yüzde 80'ini içermektedir (Seraji vd., 2019).

Acil durumlarda makro düzeydeki lojistik planlamaya; tıbbi yardım malzemeleri ve personeli, özel ekipmanlar, kurtarma faaliyetlerini yürütme ve düzeni sağlamak için gerekli birlikler ve son olarak kurtarma faaliyetlerinde kullanılan gıda ve diğer emtialar gibi malların taşınması dahil edilebilir. Koordinasyon merkezi; taş1nacak yardım malzemelerinin miktarlarına, türlerine, varış yerlerine ve bu malları taşımak için dağıtılacak araçlara karar verir. Planlama sırasında, farklı tipteki araçlar (kara, hava, demiryolu vb.) ve kapasiteleri, tedarik merkezlerinde, talep merkezlerinde veya diğer yerlerde hazır olmalıdır (Özdamar vd., 2004).

Karar vericiler; depremler, kasırgalar, su baskınları ve volkanik patlamalar gibi doğal afetlerin kriz yönetimi sürecinde, lojistik sorunlara hızlı ve etkin bir şekilde yanıt vermelidir (Barbarosoğlu vd., 2002). Afetlerden hemen sonra etkilenen bölgelerde acil yardım ihtiyacına hızlı bir şekilde müdahale edilmesi, acil durum lojistiği için kritik bir sorundur. Bu durum, son zamanlarda doğal birçok felaketin olması nedeniyle artan endişelere neden olmuş ve çeşitli bilimsel araştırmalara konu olmuştur. Acil durum lojistiği, dağıtım açısından ortaya çıkan kurtarma lojistiği problemlerini çözmek için dört farklı açıdan incelenebilir. İlk olarak, taleple ilgili bilgilerdir, örneğin zayiatın ciddiyeti, ilk arama ve kurtarma döneminde oldukça sınırlıdır ve geçmiş verileri kullanarak tahmin edilememektedir. İkincisi, acil durum lojistik kaynakları, arz tarafindaki karar vericiler için tam olarak kontrol edilemeyebilir, bu da hızlı yanıt veren acil durum lojistik dağıtım sistemine 
daha zorlayıcı konular ekler. Üçüncüsü, felaketlerden etkilenen hasarlı altyapı, yardım araçlarına bir risk oluşturabilir ve son olarak uluslararası yardım ve lojistik kaynak yönetimi sorunları acil lojistik dağıtım sürecinde dengesizlik problemleri yaratarak tüm acil lojistik sistemini daha karmaşık hale getirebilir. Bununla birlikte acil lojistik dağıtım işlemlerinin performansının iyileştirilmesi için büyük bir potansiyel söz konusudur. Örnek olarak, daha ayrıntılı acil lojistik kaynak tahsis yöntemleri ve araç gönderme stratejilerini entegre etmek gösterilebilir. Ayrıca, trafik kazalarında hayatta kalanların ve afet kaynaklı hasar koşullarının gerçek zamanlı ve doğru bilgi etkileşimlerinin sağlanması, zamana bağlı kurtarma taleplerinin güncellenmesi ve hızlı yanıt veren acil lojistik faaliyetlerinde kurtarma ve dağıtım önceliğinin ayarlanması gereklidir (Sheu, 2007).

Afet lojistiği veya insani yardım lojistiği; uygun malzemeleri uygun durumda, gerekli miktarlarda ve ihtiyaç duyulan yer ve zamanda teslim etmeye yardımcı olan sistemlerdir. Çoğunlukla mal ve teçhizatın hareketi ile ilgili olmakla birlikte, yardım lojistiği aynı zamanda felaketten etkilenen insanların yer değiştirmesini, zayiatın transferini ve yardım işçilerinin taşınmasını da kapsamaktadır. Afet mağdurlarına yardım sağlanmasının yanı sıra diğer afet yönetim operasyonlarının yerine getirilmesinde de önemli bir lojistik süreçtir (Salam, 2006; Van Wassenhove, 2006; Kováks ve Spens, 2007). Afet lojistiği aynı zamanda lojistik sistemlerin tasarımını ve operasyonunu yürüten çeşitli aktörlerin ihtiyaç duyduğu koordinasyonu da inceler (Salam, 2006). Doğal bir felaketten sonra mağdurlara yiyecek, ilaç, battaniye, çadır, hijyen ürünleri ve diğer yardım malzemeleri sağlanmalıdır. Ancak, felaket nedeniyle, etkilenen bölgedeki altyapı büyük ölçüde tahrip olabilir. Bu nedenle, yardım malzemelerini tedarikçilerinden alıp afet mağdurlarına taşıyabilmek için ara depoları da içeren yeni bir taşıma sistemi kurulmalıdır (Rath ve Gutjahr, 2014).

Afet yardımı lojistik planlaması; sağlı, yemek, barınak ve su gibi yardım dağıtım programlarında etkinliğin ve müdahalenin hızının sağlanması için çok önemlidir. Afete müdahale lojistiğinde iki ana faaliyet; yardım malzemelerinin dağıtılması ve yaralıların tahliyesidir. Yaralıların tahliyesi, öncelikle ilk müdahale aşamasında gerçekleşirken, yardım malzemelerinin dağıtımı daha uzun bir süre devam edebilir (Özdamar ve Demir, 2012). Bu durumda afet sonrası gerek insani yardım açısından gerekse yaralıların tedavi sürecinde afet lojistiğine yönelik depo yeri seçimi çok önemli hale gelmektedir. Bu kapsamda çalışmanın amacı, Giresun'da sürdürülebilir afet lojistiğine yönelik depo yeri seçimi ölçütlerinin belirlenmesi ve belirlenen ölçütler doğrultusunda ideal depo yerinin belirlenmesidir. Öyle ki, çalışmanın gerekliliği açısından Giresun'a afet depo yeri kurulmasının nedeni; şehrin yer şekilleri bakımından engebeli olması dolayısıyla sel ve heyelan felaketlerinin sık sı yaşanması olarak gösterilebilir. Ek olarak Giresun'un iç kesimlerindeki ilçelerinin fay hatlarına yakın olması da afet depo yeri kurulmasına yönelik başka bir unsur olarak değerlendirilebilir.

Çalışmanın ilerleyen bölümlerinde sırasıyla; afet lojistiği ve afet lojistiği depo yeri seçimi ile ilgili literatür araştırmasına yer verilmiş, çalışmanın yöntemlerini oluşturan AHS ile MAUT ve SAW yöntemlerinin teorik açıklamaları ortaya konmuş, yöntemin Giresun için uygulaması gerçekleştirilerek bulgular sunulmuş ve sonuç ve gelecek çalışmalara ilişkin önerilerde bulunularak çalışma sonlandırılmıştır.

\section{Literatür Araştırması}

Çalışmanın amacı ile ilişkili olarak literatür araştırması, üç alt bölümde sunulmuştur. Bu kapsamda ilk olarak sürdürülebilir lojistikle ilgili çalışmalar incelenmiştir. Bu çalışmalardan ilkinde Neto vd., (2007), lojistik ağlarda sürdürülebilirliği etkileyen ana faktörleri incelemişler, çevre ve maliyet açısından çok amaçlı programlamaya dayanan verimli lojistik ağların tasarımını iyileştirmek için genel bir çerçeve sunmuşlardır. Böylelikle çok amaçlı programlama ve veri zarflama analizi tarafından paylaşılan özelliklere dayanarak lojistik ağlarda verimliliği değerlendirmek için yeni bir yöntem oluşturmuşlardır. Bunlara ek olarak bir verimlilik göstergesi geliştirmişlerdir. Geliştirdikleri bu gösterge ile karar vericilere lojistik ağları daha iyi koordine etmenin gerekliliği ve çevre mevzuatını daha iyi ayarlamanın önemini yansıtan verileri sunmayı amaçlamışlardir.

Lee vd. (2010), sürdürülebilir lojistik ağ tasarımını belirsizlik altında araştırmışlardır. Çözüm olarak ters akımların ileri lojistik operasyonları üzerindeki etkisini göz önünde bulundurularak deterministik programlama modeli önermişlerdir. Çalışmada, sürdürülebilir lojistik ağının belirsiz özelliklerini hesaba katmak için, iki aşamalı stokastik programlama modeli, ürünlere olan talebin ve müşterilere iade edilen ürün arzının, bilinen dağıtım ile stokastik parametreler olduğu varsayılmıştır. 
Xifeng vd. (2013), sürdürülebilir kalkınma bağlamında çevresel amaçlara sahip, çok amaçlı, sınırlandırılmamış bir tesis yerleşim modeli geliştirmişlerdir. Model, bir lojistik ağ içerisindeki tesisleri stratejik olarak konumlandırarak maliyetleri ve karbondioksit emisyonlarını en aza indirgemek ve hizmet güvenilirliğini en üst seviyeye çıkarmak için geliştirilmiştir. Çalışma sonunda en uygun çözüm ve üç bileşen hedefinin makul bir karşılığı olduğu, karbondioksit emisyonlarını azaltmak ve hizmet seviyesini iyileştirmek için daha fazla lojistik tesisin açılması gerektiği belirlenmiştir.

Abbasi ve Nilsson (2016), çevresel açıdan sürdürülebilir lojistik faaliyetlerin geliştirilmesindeki temaları ve zorlukları incelemişlerdir. İskandinav ülkelerinde faaliyet gösteren lojistik hizmet sağlayıcılarından on tanesi ile yapılan vaka çalışması ile çevresel açıdan sürdürülebilir lojistik faaliyetlerin geliştirilmesi sürecinde mevcut ve gelecekteki faaliyetleri analiz etmişler ve dört zorluk kategorisi belirlemişlerdir. Bunlar: müşteri öncelikleri, yönetimsel karmaşıklık, ağ dengesizliği ile teknolojik ve yasal belirsizliklerdir.

İkinci olarak afet lojistiği ile ilgili çalışmalar incelenmiştir. Barbarosoğlu vd. (2002)'nin 1992 Erzincan depremi üzerinden afet durumunda çok ölçütlü karar verme yöntemiyle helikopter lojistik planlaması için matematiksel modelleme konusunda çalıştığı görülmektedir. Kovács ve Spens (2007), afet yardım operasyonlarında insani lojistiğin özelliklerini tanımlayarak, karmaşık afet yardımları alanında lojistik operasyonların planlanması ve yürütülmesi anlayışını daha da geliştirmeyi amaçlamış ve bu kapsamda afet yardımlarının aktörlerini, safhalarını ve lojistik süreçlerini birbirinden ayıran bir çerçeve oluşturmuşlardır. Chanta ve Sangsawang (2012), sel felaketi sırasında sığınak yeri seçimi için en uygun modeli önermişlerdir. Bu modelin hedefi, korunabilecek sel mağdurlarının sayısını en üst düzeye çıkarmak veya sabit bir mesafede sığınaklara ulaşabilmek ve tüm sel mağdurlarının en yakın sığınağa olan toplam mesafesini en aza indirmektir. Problem iki-amaçlı karma-tamsayı programlama olarak formüle edildiğinden, çözmek için epsilon-kısıtı seçilmiştir. Önerilen model, gerçek bir vaka çalışması kullanılarak test edilmiştir.

Özdamar ve Demir (2012), afet yardımı tedarik zincirlerindeki teslimatı ve toplama faaliyetlerinin lojistiğini koordine etmek amaciyla verimli bir matematiksel model ve bu modeli kullanan bir hiyerarşik kümeleme ve rota prosedürü önermişlerdir.

Kusumastuti vd. (2013), yaptıkları çalışmada Endonezya'daki yardım lojistiği ağı ile ilgili bilgiler ve röportajların yanı sıra Endonezya'daki afet yönetiminde yer alan kuruluşlardan (Sosyal Refah Bakanlığı, Sağlık Bakanlığı, Ulusal Afet Yönetimi Ajansı, Endonezya Kızıl Haçı ve Çeşitli STK'lar) ve yayınlanmış makalelerden derlenen tartışmaları araştırmışlardır. Bu verilerden yola çıkarak bir model önerisinde bulunmuşlardır.

Hadiguna vd. (2014), afet lojistiğinde web tabanlı karar destek modeli uygulaması geliştirmişlerdir. Endonezya için yapılan bu çalışmada elde edilen verileri eş zamanlı olarak Çok Ölçütlü Karar Verme (ÇÖKV) ile uyumlu hale getiren bir yazılım da oluşturulmuştur.

Dubey ve Gunasekaran (2016), sürdürülebilir insani yardım lojistiğini tanımlamış ve bu konuda bir model önerisi yapmışlardır. Sürdürülebilir kalkınma ve ekolojiyi afet yardım zincirleri, insani lojistik ve tedarik zinciri ile ilişkilendirmişlerdir. Ekolojik dengesizliklerin doğal afetlerle olan doğrudan ilgisi nedeniyle çevreye önem veren bir tedarik zinciri yapısı olan sürdürülebilir insani yardım tedarik zincirini önermişlerdir.

Şahin (2017), geçici barınma alanları yer seçimi için alternatif konum değerlendirme ve seçme problemini ele alarak sayısal ve sayısal olmayan karar ölçütlerini birlikte değerlendiren yöntemler üzerine çalışmıştır. Bunun için ÇÖKV tekniklerinden Bulanık TOPSIS ve Bulanık VIKOR yöntemlerini kullanmıştır.

Iqbal vd. (2018), Monte Carlo simülasyonu kullanarak afet lojistiği kapsamında dağıtım yerini belirleyecek istatistiksel bir model geliştirmişlerdir. Oluşturulan modelde afet durumunda kullanılacak yollar, araçlar ve zaman kisitları belirlenebilmektedir

Üçüncü grupta ise afet lojistiğinde depolama ve depo yeri seçimi için yapılan çalışmalar incelenmiştir. Hale ve Moberg (2005), kritik acil durum ekipmanı ve sarf malzemeleri için depolama alanlarının uygun sayı ve konumlarını belirlemek için lojistik yöneticileri ve tedarik zinciri süreklilik ekipleri tarafından kullanılabilecek acil durum kaynakları için bir saha seçim modeli oluşturmuşlardır.

Balcik ve Beamon, (2008), çalışmalarında insani yardım zincirleri için tesis yerleşim problemini karakterize ederek, yardım çalışanlarının etkin ve verimli olmasını sağlayacak analitik bir yaklaşım sunmuşlardır. Gelen yardımlar için oluşturulan dağıtım merkezlerinin sayısını ve yerlerini ve her dağıtım merkezinde stoklanacak 
yardım temin miktarını belirleyen maksimum örtme tipi bir model geliştirmişlerdir. Model sonuçları, yardım sistemindeki karar vericiler için önemli sonuçlara vurgu yapmaktadır.

Mete ve Zabinsky (2009), acil durumlarda kullanılacak tıbbi malzemelerin depolanmasını ve dağıtımını planlamak için olasılıksal bir programlama yaklaşımı geliştirmişlerdir.

Liu vd. (2013), acil durum malzeme depolarının yerini belirlemek için iki-amaçlı karışık tamsayılı programlama modeli kullanarak bir sezgisel algoritma tasarlamışlardır.

Davis vd. (2013), ABD'nin orta kesiminde meydana gelen hortum felaketleri için envanter yönetimi kararlarını koordinasyon kapsamında ele alarak dış tedariklerle iş birliği içerisinde bir dağıtım ağı çerçevesi oluşturmuşlar ve güvenli depo yerlerini belirlemişlerdir.

Rath ve Roh (2013), ÇÖKV yöntemleri kullanarak afet lojistiği kapsamında depo yerleri belirlemişlerdir. Ayrıca çalışmalarında ticari lojistikle insani lojistiğin karşılaştırmasını da yapmışlardır. Gutjahr (2014), üç amaçlı depo yeri belirleme sorunu için afet yardımı konusunda bir matematik-sezgisel model geliştirmişlerdir. Handayani vd. (2015), bir afet lojistik deposunun yerini belirleme ölçütlerini ve alternatif lojistik depo yerini belirlemişlerdir. Çalışmada depo lojistiğinin yerini belirleme ölçütlerini seçmek ve en uygun yeri belirlemek için AHS ve Bulanık-TOPSIS'i kullanmışlardır.

Florez vd. (2015), yaptıkları çalışmada Peru'daki bir insani tedarik zincirinin tasarımına dayanan skolastik çoklu senaryolar programı ile tesis yeri seçimi için gerçek hayattaki bir vakaya dayanan bir uygulama geliştirmişlerdir.

Roh vd. (2015), insani yardım kuruluşları için yapılan depoları hem makro (hangi ülke, hangi bölge) hem de mikro (yer) bakış açısından incelemişler ve bu kararların yönetsel sonuçlarını değerlendirmişlerdir. Çalışmada AHS kullanılarak bireysel ölçütlerin göreceli önemi belirlenmiştir.

Ashinaka vd. (2016), Tayland'ın merkezindeki deneysel bir alanı yardım malzemelerinin miktarı, önceki depoların sayısı ve acil durum için hazırlık yaparken katılması gereken pozisyonlar gibi gerçekçi veriler kullanarak tanımlamışlar ve bilgisayar programı yardımı ile benzetim uygulaması yaparak modellemişlerdir.

Boltürk vd. (2016), Türkiye'de insani yardım çerçevesi içinde insani lojistik faaliyetlerini yürütebilmek için depo yer seçimi ölçütlerini belirlemeye çalışmışlardır. Bunun için ÇÖKV tekniklerinden Bulanık AHS yöntemini kullanmışlardır. Yapılan analiz sonucunda coğrafi konum, maliyet, ulaşım bağlantıları, işgücüne erişilebilirlik ve istikrarlı hükümet ölçütlerinden önem sırasına göre maliyet en önemli ana ölçüt olarak belirlenmiştir. Demirdöğen vd. (2017), TR A1 bölgesinde (Erzurum, Erzincan, Bayburt) afet lojistiği bünyesinde dağıtım merkez yeri seçimi problemini Stokastik Kritik Kabul Edilebilirlik Analizi-2 (SMAA-2) yöntemi ile ele almışlardır.

Ofluoglu vd. (2017), yaptıkları araştırma içeriğinde Trabzon ili için afet lojistiği depo kuruluş yer seçimi sorununu ÇÖKV problemi olarak ele almışlar ve çok ölçütlü bir model tasarlamışlardır. Geliştirdikleri bu modelde öncelikle Entropi Ağırlı yöntemini kullanarak ölçüt ağırlıklarını hesaplamışlar, devamında alternatif depo yerlerini, ÇÖKV teknikleri olan SAW, TOPSIS ve VIKOR kullanarak sıralamışlardır. Elde edilen sonuçları, Borda Sayım yöntemi kullanıp birleştirerek bütünleşik bir sıralama elde etmişlerdir.

Aydın vd. (2017), çalışmalarında, acil durum malzemelerini ihtiyaç noktalarına mümkün olan en az zamanda ulaştırmak amacıyla inşa edilecek afet lojistik depoları için yer seçimi sorununu Maltepe ilçesi örneğinde araştırmışlardır. İncelenen sorun için entegre iki evreli bir model belirlenmiştir. İlk evrede, belli bir kapsama alanı için asgari felaket lojistik depo sayısını gösteren bir küme kapsama modeli önermişler, ikinci evrede, talep ağırlıklı mesafenin en aza indirilmesi için bir p-medyan modeli geliştirmişlerdir.

Rodríguez-Espíndola vd. (2017), farklı kuruluşlardan edinilen kaynakların yönetimini göz önünde bulundurarak acil durum hazırlığ için bir sistem geliştirmişlerdir. Geliştirdikleri bu sistemde, Coğrafi Bilgi Sistemleri (CBS), acil durum tesislerinin yerini belirlemek için en uygun stok ön hazırlık politikası, ilk yardım dağıtımı ile malzeme ve insan kaynakları tahsisini kullanmışlarıdır. 
Boonmee vd. (2017), yaptıkları çalışmada acil durum ve insani lojistiğin veri modelleme ve problem türlerine bağlı olarak tesis kuruluş yeri problemlerini gözden geçirmişlerdir. Ayrıca felaket öncesi ve sonrası durumlarını incelemek için en uygun modelleme yöntemlerini araştırmışlardır. Çalışmada, duyarlılık, risk ve maliyet etkinliği üzerine odaklanılmıştır.

Maharjan ve Hanaoka (2017), ani başlangıçlı felaketlere cevap verecek bir insani yardım zinciri için Nepal'in farklı bölgelerine yerleştirilecek olan depoların uygun sayısını ve yerlerini belirlemeye çalışmışlardır. Çalışma ek kısıtlamalar getirdiği için, örtü yerleşim yeri probleminin değiştirilmiş bir versiyonu kullanılmıştır. Problem, tam sayıya uygulanan dal ve sınır ile simpleks algoritması kullanılarak çözülmüştür.

Loree ve Aros-Vera (2018), sosyal maliyetlerin en aza indirilmesi ve dağıtım noktalarının ve stratejisinin en uygun şekilde yerleştirilmesi için yoksunluk maliyet fonksiyonlarını kuruluş yeri kararlarına entegre eden bir model oluşturmuşlardır. Temiz (2018), Maltepe ilçesi örneğinde afet yönetiminde lojistik depo yeri seçimi konusunu çalışmıştır. Çalışmada medyan modeli ile depo yerleri belirlenmiştir.

Wang vd. (2018), Afet yardım malzemesi lojistik ağlarının güvenilirliğini artırmak için acil durum depolarının potansiyel hasar durumunu göz önünde bulunduran Stokastik bir karışık tam sayı programlama modeli geliştirmişlerdir.

Yapılan literatür taramasında sürdürülebilir afet lojistiği depo yeri seçimi faktörlerinin belirlenmesi ve ideal depo yeri seçimi sıralamasına yönelik sınırlı sayıda çalışma belirlenmiştir. Bu çalışmalardan biri olan Peker vd. (2016) çalışmasında Erzincan ili düzeyinde deprem olgusuna karşı dağıtım merkezi yer seçimini AHSVIKOR bütünleşik yaklaşımı ile ele almıştır. Başka bir çalışmada Ofluoğlu vd. (2017) Doğu Karadeniz Bölgesi'ndeki beş il (Trabzon, Rize, Artvin, Gümüşhane, Bayburt) için alan olarak tespit edilen Trabzon'da afet lojistiği bünyesinde depo kuruluş yer seçimi problemini ÇÖKV yöntemleri ile incelemişlerdir.

$\mathrm{Bu}$ çalışmada ise Giresun'daki diğer doğal afetler (sel, heyelan gibi) için sürdürülebilir ideal afet depo yeri seçimi konusu üzerinde durulmuştur. Öte yandan çalışma, yukarıda sayılan ilgili çalışmalardan hem yöntem olarak hem de afet lojistiği anlamında odaklanılan unsurlar yönünden ayrılmaktadır. Ek olarak çalışmanın Giresun'da gerçekleştirildiği düşünüldüğünde diğer çalışmalardan coğrafi olarak da farklılık arz ettiği söylenebilir. Ayrıca sürdürülebilir afet lojistiği depo yeri seçimi konusunda AHS-MAUT ve SAW bütünleşik yaklaşımının kullanıldığı başka bir çalışmaya da rastlanmamıştır. Bu nedenle bu çalışmanın literatüre katkı sağlayacağı değerlendirilmektedir.

\section{Araştırmanın Yöntemi}

Bu çalışmada sürdürülebilir afet lojistiği depo yeri seçimi faktörlerinin belirlenmesi ve ideal depo yeri seçiminin tespitine yönelik iki aşamalı bütünleşik bir ÇÖKV yaklaşımından yararlanılmıştır. İlk aşamada AHS ile belirlenen ölçüt ağırlıkları doğrultusunda ikinci aşamada, MAUT ve SAW yöntemleri ile alternatifler sıralanmıştır. Bu bölümde sürdürülebilir afet lojistiği depo yeri seçimi faktörlerinin belirlenmesi ve ideal depo yeri seçimi alternatiflerinin sıralanmasında kullanılan AHS, MAUT ve SAW yöntemlerinin teorik açıklamalarına yer verilmiştir.

\subsection{Analitik Hiyerarşi Süreci (AHS) Yöntemi}

Saaty tarafından 1977 yılında ortaya çıarılan yöntem karar verme ve ölçmede kullanılan matematiksel bir yaklaşımdır (Saaty ve Niemira, 2006). Yöntemin uygulama adımları aşağıdaki şekildedir:

1. Aşama: Hiyerarşik Yapının Oluşturulması: Bu aşamada alternatifler, amaç ve ölçütler belirlenerek hiyerarşik yapı oluşturulmaktadır (Saaty, 2008).

2. Aşama: Önceliklerin Belirlenmesi: Saaty tarafından 1994 yılında geliştirilen önceliklendirme ölçeği (“1 - 9”), nxn boyutlu bir kare matrisi olup ölçütler arası karşılaştırma matrisi olarak ifade edilir. 
Tablo 1

AHS ölçeği tablosu

\begin{tabular}{cll}
\hline $\begin{array}{c}\text { Önem } \\
\text { Derecesi }\end{array}$ & \multicolumn{1}{c}{ Tanım } & \multicolumn{1}{c}{ Açıklama } \\
\hline 1 & Eşit Önem & İki faaliyet eşit derece etkili \\
\hline 3 & Orta Derce Önem & $\begin{array}{l}\text { Kanaatler bir faaliyeti diğerine oranla } \\
\text { biraz tercih ediyor. }\end{array}$ \\
\hline 5 & Kuvvetli Derece Önem & $\begin{array}{l}\text { Kanaatler bir faaliyeti diğerine oranla } \\
\text { güçlü tercih ediyor. }\end{array}$ \\
\hline 7 & Çok Kuvvetli Derece Önem & $\begin{array}{l}\text { Bir faaliyet diğerine oranla güçlü ter- } \\
\text { cih ediliyor. Farkl1lı uygulamada } \\
\text { rahatlıkla görülebiliyor. }\end{array}$ \\
\hline 9 & Aşırı Derece Önem & $\begin{array}{l}\text { Bir faaliyet diğerine oranla daha güçlü } \\
\text { tercih ediliyor, delillerin güvenirliliği } \\
\text { yüksek. }\end{array}$ \\
\hline $2,4,6,8$ & Ortalama Değerler & $\begin{array}{l}\text { İki ardışı düzey arasında kararsız } \\
\text { kalınırsa ortalama değer olarak kulla- } \\
\text { nılıyor. }\end{array}$ \\
\hline
\end{tabular}

Kaynak: (Eleren, 2006).

3. Aşama: Özvektörün (Göreli Önem Vektörünün) Belirlenmesi: Önem dağılımlarına yönelik olarak belirlenen kriterlerin yüzzde dağılımları için Denklem (3.1)'den faydalanılır (Saaty, 2008).

$$
b_{i j}=\frac{a_{i j}}{\sum_{i=1}^{n} a_{i j}}
$$

$n$ sayıdaki B sütun vektörü ise, matris formatı olarak toplanır ve aşağıda verilen C matrisi meydana gelir.

$$
\begin{gathered}
C=\left[\begin{array}{cccc}
c_{11} & c_{12} & \ldots & c_{1 n} \\
c_{21} & c_{22} & \ldots & c_{2 n} \\
\cdot & & & \cdot \\
\cdot & & & \cdot \\
\cdot & & & \cdot \\
c_{n 1} & c_{n 2} & \ldots & c_{n n}
\end{array}\right] \\
w_{i}=\frac{\sum_{j=1}^{n} c_{i j}}{n}
\end{gathered}
$$

4. Aşama: Tutarlılık Oranının Hesaplanmast: AHS yönteminde (CR) tutarlılık oranıdır. Özellikle kriterler arası yapılan karşılaş̧ırmaların tutarlılığının ölçülmesine imkan verir (Saaty, 2008). 


$$
\begin{aligned}
D & =\left[\begin{array}{cccc}
a_{11} & a_{12} & \ldots & a_{1 n} \\
a_{21} & a_{22} & \ldots & a_{2 n} \\
\cdot & & & \cdot \\
\cdot & & & \cdot \\
\cdot & & & \cdot \\
a_{n 1} & a_{n 2} & \ldots & a_{n n}
\end{array}\right]\left[\begin{array}{c}
w_{1} \\
w_{2} \\
\cdot \\
\cdot \\
\cdot \\
w_{n}
\end{array}\right] \\
E_{i} & =\frac{d_{i}}{w_{i}} i=1,2, \ldots, n \\
\lambda & =\frac{\sum_{i=1}^{n} E_{i}}{n}
\end{aligned}
$$

$\lambda$ hesap edildikten sonra Denklem (3.5)'den faydalanılarak Tutarlılık Göstergesi (CI), hesap edilir.

$$
C I=\frac{\lambda-n}{n-1}
$$

Son olarak da Denklem (3.6)'dan faydalanılarak CR değeri bulunur.

$$
C R=\frac{C I}{R I}
$$

Analizler sonucu elde edilen CR değeri 0,10'dan küçük ise, yapılan analizin geçerli olduğunun göstergesidir.

\subsection{MAUT Yöntemi}

MAUT yöntemi, Fisburn (1967) ve Keeney (1974) tarafindan niceliksel ve niteliksel ölçütler göz önünde bulundurularak en yararlı alternatifi bulmak için geliştirilen yöntemlerden biridir. (Løken ve Botterud, 2007). Özellikle günümüzde gelişen ve karmaşıklaşan dünyadaki gerçek bir karar probleminin analizine ilişkin olarak MAUT yönteminden faydalanılır (Konuşkan ve Uygun, 2014). Çünkü bu yöntem niceliksel ve niteliksel kriterler baz alınarak en yararlı alternatifi bulmaya yönelik uygulamalardır. Öyle ki MAUT yönteminde nesnel veriler, hesaplanabilir hale getirilerek en çok fayda sağlayan alternatifin bulunması amaçlanır (Loken ve Botterud, 2007). Öte yandan yöntem, çelişmekte olan hedefler arasındaki seçimin yapılması için çözülebilir ve mantıklı bir bileşen sağlaması sebebi ile diğer ÇÖKV yöntemlerinden ayrılır. Karara varmak ve ortak bir temele oturtmak için düzenli bir biçimde çalışmaya da olanak veren bir yapısı vardır (Kim ve Song, 2009). Temelde her karar verici bilinçli ya da dolaylı yoldan tüm bakış açılarını bir araya getirerek iyileştirmeye çalışır. Karar vericinin tercihleri, temsil edilen fayda fonksiyonu anlamına gelmektedir. Karar vericinin bu fonksiyonu karar verme sürecinin başında bilmesine gerek yoktur bu yüzden öncelikle fonksiyonu inşa etmek zorundadır. Fayda fonksiyonu, tercih edilebilirlik veya alternatifleri ölçmenin bir yoludur (Tunca vd., 2016). Dolayısıyla son yıllarda gelişen dünyada gerçek bir analiz yapmak için MAUT yöntemini kullanmak olağan hale gelmiştir (Konuşkan ve Uygun, 2014).

Ayrıca karmaşık ve kompleks yapısı itibari ile gerçek hayatta karşılaşılan sorunların belirlenmesinde karar verenler görüşlerini doğru olarak yansitamayabilirler veya düşüncelerini doğru bir biçimde gösteremeyebilirler. Bir diğer ifade ile ölçüt değerlerinin kesin ifadelerle ortaya koyulamadığ 1 durumlarla karşılaşılabilir. Bu durumlar için bulanık mantığın kullanılması daha yerinde olmuştur. (Zadeh, 1965).

MAUT yönteminin adımları aşağıda verilmiştir (Ishizaka ve Nemery, 2012; Konuşkan ve Uygun, 2014): 
1. Adım: Ölçütlerin ve Alternatiflerin Belirlenmesi: Karar problemine ilişkin ölçütler $\left(\mathrm{a}_{\mathrm{n}}\right)$ ve alternatifler $\left(\mathrm{x}_{\mathrm{m}}\right)$ belirlenmelidir.

2. Adım: Ă̆ırlık Değerlerinin Belirlenmesi: Doğru bir biçimde alternatiflerin değerlendirilmesine imkân veren ve önceliklerin tespit edildiği ağırlık değerlerine $\left(\mathrm{w}_{\mathrm{j}}\right)$ ataması yapılır. Bütün $\left(\mathrm{w}_{\mathrm{j}}\right)$ değerlerinin toplamı 1'e eşit olması gerekmektedir.

$$
\sum_{i}^{m} w j=1
$$

3. Adım: Karar Matrisinin Belirlenmesi: Ölçütlerin değer ölçülerinin ataması yapılmasında nitel ölçütler ölçütler için ikili karşılaştırmalar göz önünde bulundurulur, nicel ölçütler için ise nicel değerlere göre atama yapılır. Tüm bu göstergelerin 1şı̆̆ında, 5'lik, 100'lük vb. sistemde değer atamaları yapılır $\left(\mathrm{x}_{\mathrm{m}}\right)$.

4. Adım: Normalize Edilmiş Fayda Değerlerinin Hesaplanması: Normalizasyon sürecinde temelde her niteliğe yönelik en kötü ve en iyi değerler tespit edilerek en kötü değere 0 ve en iyi değere 1 atamas1 yapılır ve öteki değerlerin hesaplanmasında Denklem (8)'de verilen formülden faydalanılır.

$$
f j(a i)=\frac{\mathrm{f} i(a i)-\min (\mathrm{f} i)}{\max (\mathrm{f} i)-\min (f i)}
$$

5. Adım: Toplam Fayda Değerlerinin Hesaplanmast: Yapılan normalizasyon sürecinden sonra fayda değerlerinin tespit edilmesine geçilir. Denklem (9)'da fayda fonksiyonuna yönelik formül verilmiştir.

$$
U(a i)=\sum_{j=1}^{q} f i(a i) \cdot w j
$$

\subsection{SAW Yöntemi}

Churchman ve Ackoff (1954) geliştirdikleri bu yöntemde aşağıda verilen eşitlikler kullanılarak önce matris normalleştirme daha sonra ise alternatiflerin sıralanması işlemleri gerçekleştirilir. Büyükten küçüğe doğru alternatiflerin aldıkları değerler sıralanır ve en yukarıdaki alternatifin, performansı en iyi alternatif olduğu kabul edilmektedir. (Savitha ve Chandrasekar, 2011).

SAW yönteminin adımları aşağıda verilmiştir (Janic ve Reggiani, 2003; Yeh, 2003):

Adım 1: Karar Matrisinin Normalize Edilmesi: SAW Yönteminde ilk aşamada m sayıda alternatif ve $n$ sayıda değerlendirme ölçütünden oluşan karar matrisi yukarıdaki Denklik (10)'dan faydalanılarak normalize edilir.

$$
\mathrm{r}_{\mathrm{ij}}=\left\{\begin{array}{l}
\frac{x i j}{\operatorname{maxxij}} i=1, \ldots, m ; j=1, \ldots ., n \\
\frac{m i n x i j}{x i j} i=1, \ldots, m ; j=1, \ldots, n
\end{array}\right.
$$

Adım 2: Alternatiflerin Tercih Değerlerinin Hesaplanması: Her bir ölçüt ağırlığı ile daha önce hesaplanmış olan değerlerinin çarpılması sonucunda her bir alternatifin toplam tercih değerleri hesaplanmış olur.

$$
\mathrm{S}_{\mathrm{j}}=\sum_{j=1}^{m} W j r i j \quad, \mathrm{i}=, \ldots, \mathrm{m},
$$

\section{Uygulama}

Çalışmada sürdürülebilir afet lojistiğine yönelik ideal afet depo yeri seçimi için ölçütlerin belirlenmesi ve ideal afet depo yeri seçimine ilişkin alternatiflerin değerlendirilmesi amacıyla iki aşamalı çok ölçütlü karar modeli oluşturulmuştur. 


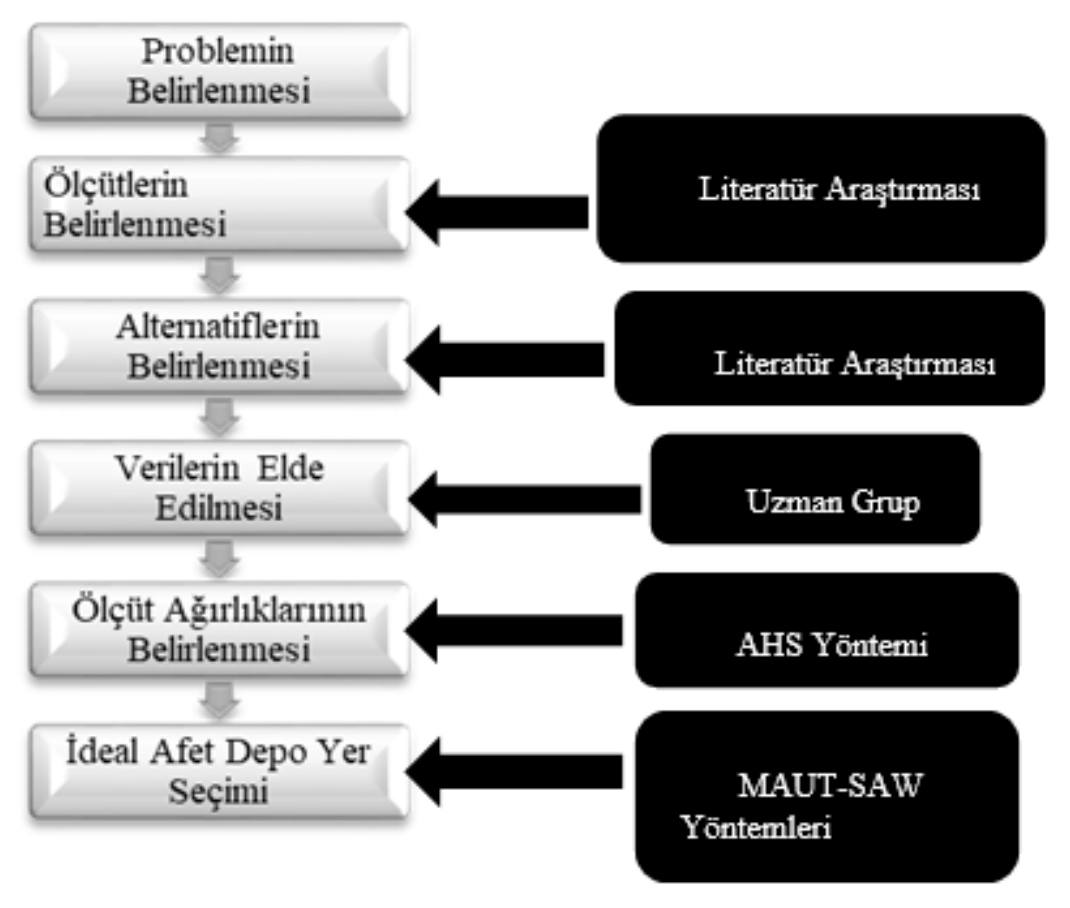

Şekil 1. Çalışma uygulama adımları

Şekil 1'de yer alan uygulama adımlarındaki sıraya göre işlemler yapılmıştır. Buna göre ilk olarak karar modeline göre literatür taraması ve uzman görüşleri yararlanılarak sürdürülebilir afet lojistiğine yönelik ideal afet depo yeri seçimine ilişkin ölçütler belirlenmiş̧ir. Belirlenen ölçütler aynı önem düzeyine sahip olmadığından, ölçütlerin önceliklendirilmesine gerek duyulmaktadır. Bu kapsamda, AHS yöntemi ile sürdürülebilir afet lojistiği afet depo yeri seçimi ölçütleri ağırlıklandırılmıştır. Ağırlıklandırılmış ölçütler kullanılarak da hem MAUT hem de SAW yöntemleri ile afet lojistiğine yönelik ideal afet depo yeri seçimi yapılmıştır.

Ölçütler belirlenirken Kızılay'dan (3), Afet ve Acil Durum Müdürlüğü’nden (5), Yerel Yönetimler'den (3), Sivil Toplum Kuruluşları'ndan (3), Akademisyenler'den (3), lojistik hizmet alan firmalardan (5) ve lojistik hizmet veren firmalardan (5) olmak üzere toplam 27 uzmandan görüş alınmıştır. Ayrıca ilgili literatürün taranmasından da faydalanılarak aşağıdaki tablo (Tablo 2) oluşturulmuştur. Öte yandan Samsun Afet ve Acil Durum Arama ve Kurtarma Birlik Müdürlüğü ile koordineli bir biçimde hareket eden ve bağlı illerde (Samsun, Amasya, Sinop, Tokat, Trabzon, Ordu, Kastamonu ve Giresun) arama ve kurtarma faaliyeti yapan sivil toplum kuruluşları da çalışmaya dâhil edilmiştir. Ölçütler belirlenirken literatür taramasının yanında uzman gruptan gelen (depolara ve gıda temin noktalara uzaklık, arazinin zemini gibi) unsurlar da eklenmiş ve karar ölçütleri oluşturulmuştur. 
Tablo 2

Karar ölçütleri

\begin{tabular}{|c|c|c|}
\hline Ana Ölçütler & Alt Ölçütler & Kaynak \\
\hline \multirow{7}{*}{ Konum $\left(\mathrm{K}_{1}\right)$} & $\begin{array}{l}\text { Afete Maruz Kalanlara Ulaşım } \\
\text { Süresi }\left(\mathrm{K}_{11}\right)\end{array}$ & $\begin{array}{l}\text { Peker vd. (2016), Uzman } \\
\text { Görüşleri }\end{array}$ \\
\hline & Yerleşim Yerine Uzaklık $\left(\mathrm{K}_{12}\right)$ & Roh vd. (2013). \\
\hline & $\begin{array}{l}\text { Depolara ve Gida Temin Edilecek } \\
\text { Noktalara Uzaklık }\left(\mathrm{K}_{13}\right)\end{array}$ & Uzman Görüşleri. \\
\hline & Kara Yoluna Uzaklık $\left(\mathrm{K}_{14}\right)$ & $\begin{array}{l}\text { Awasti vd (2011), Peker vd. } \\
\text { (2016). }\end{array}$ \\
\hline & Hava Yoluna Uzaklık $\left(\mathrm{K}_{15}\right)$ & Kuo (2011). \\
\hline & Deniz Yoluna Uzaklık $\left(\mathrm{K}_{16}\right)$ & Roh vd. (2013). \\
\hline & Arazi Maliyetleri $\left(\mathrm{K}_{17}\right)$ & Yang vd. (2011). \\
\hline \multirow{6}{*}{ Altyap $1\left(\mathrm{~K}_{2}\right)$} & Afetsellik Yap1sı $\left(\mathrm{K}_{21}\right)$ & Peker vd. (2016). \\
\hline & Arazinin Zemini $\left(\mathrm{K}_{22}\right)$ & Uzman Görüşleri. \\
\hline & Arazi Tapu Bilgileri $\left(\mathrm{K}_{23}\right)$ & Chan vd. (2007). \\
\hline & İş Gücünün Durumu $\left(\mathrm{K}_{24}\right)$ & $\begin{array}{l}\text { Kobu (2008), Peker vd. } \\
\text { (2016). }\end{array}$ \\
\hline & $\begin{array}{l}\text { Sel, Toprak Kayması ve } \text { Firtına } \\
\text { Riski }\left(\mathrm{K}_{25}\right)\end{array}$ & Uzman Görüşleri. \\
\hline & Fay Geçme Durumu $\left(\mathrm{K}_{26}\right)$ & Uzman Görüşleri. \\
\hline \multirow{4}{*}{ İş Birliği $\left(\mathrm{K}_{3}\right)$} & $\begin{array}{l}\text { Lojistik Hizmet Veren Firmalar } \\
\left(\mathrm{K}_{31}\right)\end{array}$ & $\begin{array}{l}\text { Roh vd. (2013), Peker vd. } \\
\text { (2016), Uzman Görüşleri. }\end{array}$ \\
\hline & Üniversite $\left(\mathrm{K}_{32}\right)$ & $\begin{array}{l}\text { Roh vd. (2013), Peker vd. } \\
\text { (2016), Uzman Görüşleri. }\end{array}$ \\
\hline & Sivil Toplum Kuruluşları $\left(\mathrm{K}_{33}\right)$ & $\begin{array}{l}\text { Roh vd., (2013), Peker vd. } \\
\text { (2016), Uzman Görüşleri. }\end{array}$ \\
\hline & Hükümet Teşvikleri $\left(\mathrm{K}_{34}\right)$ & $\begin{array}{l}\text { Roh vd., (2013), Peker vd. } \\
\text { (2016), Uzman Görüşleri. }\end{array}$ \\
\hline
\end{tabular}

Gerek uzman grubun görüşleri gerekse yapılan literatür taramasında sürdürülebilirlik temasına yönelik herhangi bir ölçüt seti saptanamamıştır. Alt ölçütlerin oluşturulduğu ana ölçütlerin isimlendirilmesi; Chan vd. (2007), Kuo (2011), Roh vd. (2013) ve Peker vd. (2016) tarafından yapılan çalışmalar ile uzman grubun görüşlerinden yararlanılarak oluşturulmuştur. 


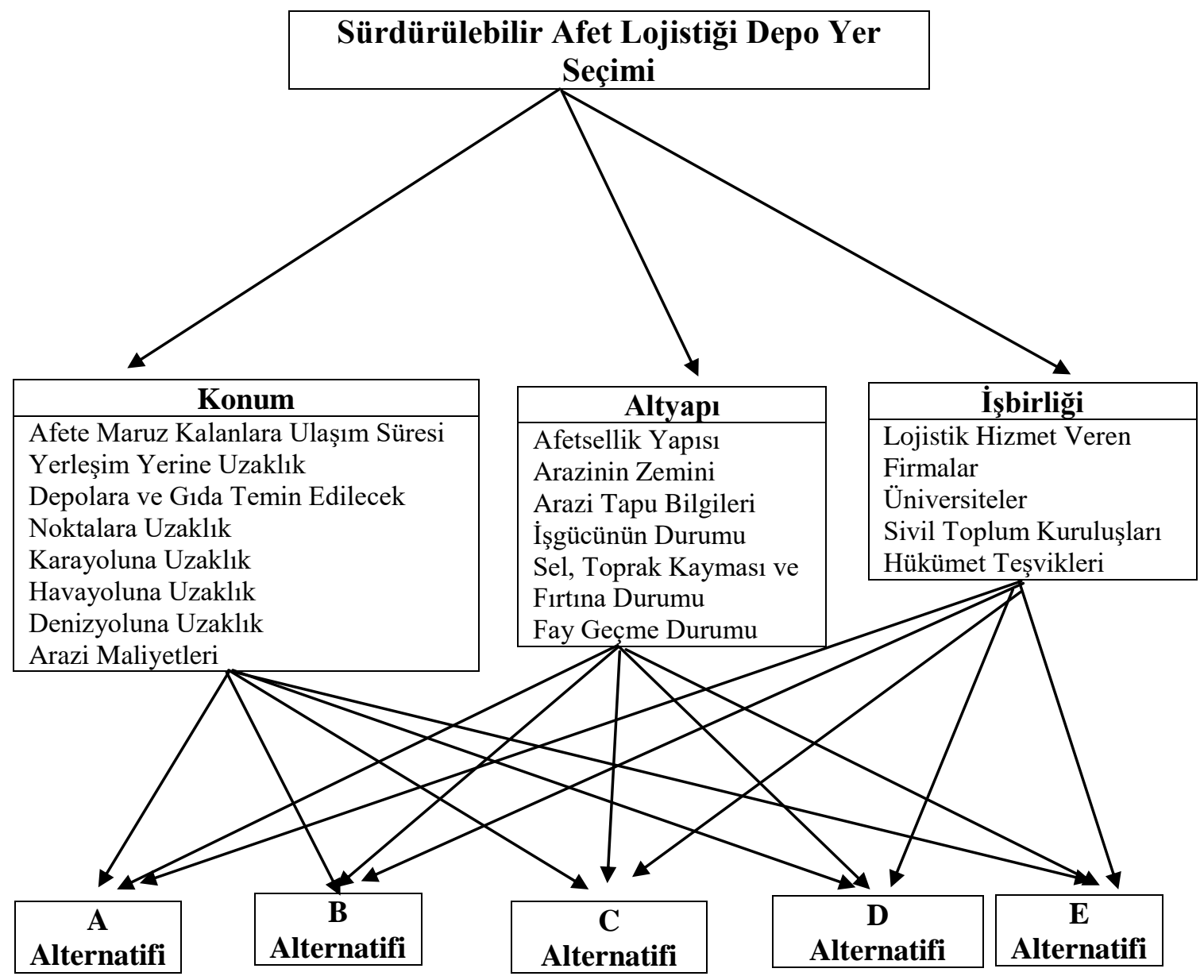

Şekil 2. Hiyerarşik yap1

\section{1. Ölçütlerin Ağırlıklandırılması}

AHS yönteminden faydalanılan bu adımda ölçütlerin değerlendirilmesine yönelik ikili karşılaştırma anketi oluşturularak, paydaşlar olan Kızılay’1 (3), Afet ve Acil Durum Müdürlüğü’nü (5), Yerel Yönetimler'i (3), Sivil Toplum Kuruluşları'nı (3), akademisyenleri (3) ve lojistik hizmet veren firmalar (5) ile lojistik hizmet alan firmaları (5) temsilen toplam 27 uzmana anket sunulmuştur. Görüşlere ilişkin tablolar; Ek:1, Ek:2, Ek:3 ve Ek:4'te verilmiştir. AHS önem ölçeğine göre oluşturulan ikili karşılaştırma matrisi ile belirlenen ölçütlerin ağırlıkları bulunmuş ve Tablo 3'te verilmiştir. Bu kapsamda tutarlık analizi yapılmış ve $C R$ değeri 0,095 olarak belirlenmiştir. CR 0,095 < 0,10 olduğundan sonuçlar tutarlı olarak değerlendirilmiştir. 
Tablo 3

Ölçütlere ilişkin ağırlık değerleri

\begin{tabular}{lll}
\hline Ana Ölçüt & Alt Ölçüt & Ăğırlıklar \\
\hline $\mathrm{K}_{1}=0,067$ & $\mathrm{~K}_{11}$ & 0,022 \\
& $\mathrm{~K}_{12}$ & 0,011 \\
& $\mathrm{~K}_{13}$ & 0,019 \\
& $\mathrm{~K}_{14}$ & 0,007 \\
& $\mathrm{~K}_{15}$ & 0,004 \\
& $\mathrm{~K}_{16}$ & 0,002 \\
& $\mathrm{~K}_{17}$ & 0,002 \\
\hline & $\mathrm{K}_{21}$ & 0,232 \\
$\mathrm{~K}_{2}=0,640$ & $\mathrm{~K}_{22}$ & 0,151 \\
& $\mathrm{~K}_{23}$ & 0,026 \\
& $\mathrm{~K}_{24}$ & 0,110 \\
& $\mathrm{~K}_{25}$ & 0,063 \\
& $\mathrm{~K}_{26}$ & 0,058 \\
\hline $\mathrm{K}_{3}=0,293$ & $\mathrm{~K}_{31}$ & 0,013 \\
& $\mathrm{~K}_{32}$ & 0,162 \\
& $\mathrm{~K}_{33}$ & 0,080 \\
$\mathrm{~K}_{34}$ & 0,038 \\
\hline
\end{tabular}

Tablo 3'e göre afet lojistiğine yönelik afet depo yeri seçimi için en önemli ana ölçütün "Altyapı" olduğu belirlenmiştir. Öte yandan afet depo yeri seçimine ait "Konum” ölçütü ise en az önemli ölçüt olmuştur.

Çalışmadaki tüm alt ölçütler incelendiğinde, modeli en çok etkileyen alt ölçütün "Afetsellik Yapısı" olduğu belirlenmiştir. Modeldeki tüm alt ölçütler açısından ikinci sırada yer alan ve modeli en çok etkileyen diğer alt ölçütün ise "Üniversite" olduğu belirlenmiştir. Tüm alt ölçütlere yönelik en düşük öneme sahip ve modeli en az etkileyen alt ölçütler ise, "Deniz Yoluna Uzaklık" ile "Arazi Maliyetleri”dir.

\subsection{Alternatiflerin Siralanması}

Çalışmaya ilişkin alternatiflerin belirlenmesi aşamasında uzman grubun görüşleri dikkate alınmış ve kendilerine hangi noktaların afet depo yeri olacağı sorulmuştur. Bu alternatifler; organize sanayi bölgesi, hava yoluna yakın alanlar, deniz yoluna yakın alanlar, kara yolu geçiş güzergâhları, Trabzon'a yakın olması sebebi ile Görele ilçesindeki karayolu ve deniz yolu geçiş noktaları, şehrin merkezine yakın bir nokta ile şehrin iç kesimlerinde herhangi bir afet durumunda müdahale edilebilmesi için Tirebolu ile Doğankent arasında bir yer olarak başlangıçta 7 nokta olarak belirlenmiştir.

Belirlenen alternatifler için 1-5 arası puan ölçeğini içeren anket uzman grubun tümüne (27) uygulanmış ve en çok oyu alan beş muhtemel afet depo yeri için karar matrisleri oluşturularak uzman gruba yeniden sorulmuştur.

Bu kapsamda beş alternatifin sıralanması için hem MAUT hem de SAW yöntemlerinden faydalanılmıştır. AHS ile saptanan ölçütlerin ağırlıklarından yararlanılarak MAUT ve SAW yöntemleri ile sürdürülebilir afet 
lojistiğine yönelik ideal afet depo yeri seçimi yapılmıştır. Bu doğrultuda her iki yöntem için ayrı ayrı karar matrisleri oluşturulmuş ve sonrasında karar matrisleri normalleştirilmiştir. Görüşlere ilişkin tablolar; Ek:5, Ek:6, Ek:7, Ek:8, Ek:9 ve Ek:10'da sunulmuştur. Bu kapsamda MAUT yöntemi ile tespit edilen siralama değerleri aşağıdaki Tabloda gösterilmiştir.

Tablo 4

MAUT yöntemi sıralama sonuçları

\begin{tabular}{clllcc}
\hline Alternatifler & $\mathrm{K}_{1}$ & $\mathrm{~K}_{2}$ & $\mathrm{~K}_{3}$ & $\begin{array}{r}\text { Toplam Fayda } \\
\text { Değeri }\end{array}$ & Siralama \\
\hline $\mathbf{A}_{\mathbf{1}}$ & 0 & 0 & 0,293 & 0,293 & 4 \\
\hline $\mathbf{A}_{\mathbf{2}}$ & 0,045 & 0,640 & 0,293 & 0,978 & 1 \\
\hline $\mathbf{A}_{\mathbf{3}}$ & 0,067 & 0 & 0 & 0,067 & 5 \\
\hline $\mathbf{A}_{\mathbf{4}}$ & 0,022 & 0,320 & 0 & 0,342 & 3 \\
\hline $\mathbf{A}_{\mathbf{5}}$ & 0,067 & 0,320 & 0,147 & 0,534 & 2 \\
\hline
\end{tabular}

MAUT yöntemi sonucunda elde edilen Tablo 4'e göre, sürdürülebilir afet lojistiğine yönelik ideal afet depo yeri seçimi sıralamasında Giresun'da $A_{2}$ seçeneği ideal afet depo yeri olarak belirlenmiştir. Öte yandan ideal afet depo yeri seçeneklerin genel sıralaması ise $A_{2}>A_{5}>A_{4}>A_{1}>A_{3}$ şeklinde gerçekleşmiştir.

Diğer taraftan bir diğer yöntem olan SAW ile tespit edilen sıralama sonuçları Tablo 5’te sunulmuştur.

Tablo 5

SAW yöntemi sıralama sonuçları

\begin{tabular}{cccccc}
\hline Alternatifler & $\mathrm{K}_{1}$ & $\mathrm{~K}_{2}$ & $\mathrm{~K}_{3}$ & $\begin{array}{l}\text { Toplam } \\
\text { Tercih } \\
\text { Değeri }\end{array}$ & \\
\hline $\mathbf{A}_{\mathbf{1}}$ & 0,045 & 0,512 & 0,147 & 0,196 & 3 \\
\hline $\mathrm{A}_{2}$ & 0,045 & 0,640 & 0,293 & 0,274 & 1 \\
\hline $\mathrm{A}_{3}$ & 0,045 & 0,256 & 0,146 & 0,126 & 5 \\
\hline $\mathrm{A}_{4}$ & 0,034 & 0,512 & 0,293 & 0,236 & 2 \\
\hline $\mathrm{A}_{5}$ & 0,067 & 0,384 & 0,147 & 0,168 & 4 \\
\hline
\end{tabular}

SAW yöntemi sonuçlarını ortaya koyan Tablo 5'e göre, sürdürülebilir afet lojistiğine yönelik ideal afet depo yeri seçimi sıralamasında $A_{2}$ seçeneği ideal afet depo yeri olmuştur. İdeal afet depo yeri seçeneklerinin genel sıralaması ise $A_{2}>A_{4}>A_{1}>A_{5}>A_{3}$ şeklinde gerçekleşmiştir.

Her iki yöntemin sonuçları birlikte değerlendirildiğinde Giresun ili için sürdürülebilir afet lojistiği açısından ideal afet depo yerinin $A_{2}$ olduğu belirlenmiştir. En az öneme sahip ideal afet depo yeri ise her iki yöntem 
için de $\mathrm{A}_{3}$ alternatifidir. Ayrı yöntemler için benzer sonuçların elde edilmesi, çalışmanın tutarlılığını ve doğruluğunu gösteren bir bulgu olarak değerlendirilmektedir.

\section{Sonuç}

Afet durumunda ihtiyaç duyulan malzemelerin temin edilmesi ve gerekli müdahalelerin yapılması, afete maruz kalan kimselerin hayatta kalmasına doğrudan etki eden çok önemli uygulamalardır. Özellikle gerekli olan malzemenin doğru, dinamik ve süratli bir biçimde yerine ulaştırılması, etkin afet depo yeri seçimi bileşenlerinin dikkatli bir biçimde incelenmesi ve analiz edilmesine bağlıdır.

Depo yer seçimi afet lojistiğinin etkinliği ve sürdürülebilirliği açısından hayati derecede öneme sahiptir. Çünkü afet lojistiğinde depolama fonksiyonu en az operasyon kadar önemlidir. Afetin şiddetine ve türüne göre birey, aile, bina, tesis, bölge bazında farkl1l1k göstermekte ve müdahale gerektirmektedir. Hiyerarşik baz da olan afet lojistiği ve yönetiminin sürdürülebilir kılınması afet öncesi, afet sırası ve afet sonrası çalışmalarının belirlenmiş hedefler doğrultusunda mevcut kaynakların en etkin ve verimli bir şekilde kullanılarak yönetimine bağlıdır. Ayrıca sürdürülebilir afet lojistiği için ekolojiden kaynaklı dengesiz durumların doğal afetlerle olan doğrudan ilgisi sebebi ile oluşturulacak afet lojistiği yapısının sürdürülebilir insani yardım tedarik zinciri ile entegre olması gereklidir.

Bu çerçevede sürdürülebilir afet lojistiği için ideal afet depo yeri seçimi karmaşık bir karar verme problemi olmakla birlikte alternatifler arasında en uygun olanının belirlenmesi ÇÖKV yöntemlerinden yararlanmayı gerektirmektedir.

$\mathrm{Bu}$ çalışmanın temel amac1, sürdürülebilir afet lojistiğine yönelik depo yeri seçimi ölçütlerinin belirlenmesi ve belirlenen ölçütler doğrultusunda ideal afet depo yerinin belirlenmesidir. Bu kapsamda ÇÖKV yöntemlerinden AHS, MAUT ve SAW yöntemleri göz önüne alınarak, sürdürülebilir afet lojistiğine yönelik ideal afet depo yeri seçimi için belirlenen ölçütler ağırlıklandırılmış ve bu ağırlıklar kullanılarak ideal afet depo yeri seçimi yapılmıştır.

Yapılan çalışma sonucuna göre, sürdürülebilir afet lojistiğine yönelik ideal afet depo yeri seçiminde en önemli ana ölçüt altyapı $\left(\mathrm{K}_{2}\right)$ olarak saptanmıştır. Bu durum Roh vd. (2013) tarafından yapılan çalışmanın bulgularıyla benzeşmektedir. Ayrıca, konum $\left(\mathrm{K}_{1}\right)$, en az önemli ana ölçüt olarak belirlenmiştir. Bu durum ise Peker vd. (2016)'nin yaptığı çalışmanın sonuçları ile örtüşmemektedir.

En önemli alt ölçütün ise, "afetsellik yapısı" olduğu belirlenmiştir. Bu durum Peker vd., (2016) tarafindan yapılan çalışmanın bulgularıyla benzeşmektedir. Ayrıca "deniz yoluna uzakllk" ve "arazi maliyetleri" en az öneme sahip alt ölçütler olmuştur. Bu iki alt ölçütün en az öneme sahip olmaları, Peker vd. (2016) ile Ofluoğlu vd. (2017)'nin elde ettiği bulgular ile örtüşmektedir.

MAUT ve SAW yöntemleri kullanılarak gerçekleştirilen ideal afet depo yeri seçimi sonuçları ise her iki yöntem için de $\mathrm{A}_{2}$ 'nin en ideal afet depo yeri alternatifi olduğunu göstermiştir. Çalışmada her iki yöntemin (MAUT-SAW) sonuçları kıyaslandığında büyük oranda aynı sonuçlara ulaşılması, çalışmanın doğruluğunu ve tutarlılı̆̆ını artıran bir unsur olarak değerlendirilebilir.

Ulaşı1lan sonuçlara göre; $A_{2}$ alternatifini ön plana çıkaran temel unsurun altyapı ve alt faktörün ise afetsellik yapısı olduğu söylenebilir. Ancak $A_{2}$ alternatifinin kara, hava ve deniz yoluna yakınlık sebebi ile uzman grup tarafindan tercih edildiği değerlendirilebilir. Ayrıca $\mathrm{A}_{2}$ alternatifinin; doğal afetlerden etkilenme durumu, arazinin topografyası ve jeolojik yapısı, iş gücü çeşitliliği, lojistik alanında akademik ve sektörel uzman/işgücü çeşitliliğinin varlığı, karayolu, denizyolu ve havayolu geçiş güzergahlarına yakınlık ve depo kuruluşu için optimal maliyet gibi öğeler açısından taşıdığı avantajların da bu seçimde etkili olduğu söylenebilir. Bununla birlikte ilgili yerin şehrin Doğu kısmına nispeten uzak olması, olası bir afet durumunda o yöredeki insanlara ulaşmada zaman ve maliyet noktasında olumsuz yansımaları da ortaya çıkarabilecektir.

Elde edilen bulgular konunun paydaşları olan Kızılay, Afet ve Acil Durum Müdürlüğü, Yerel Yönetimler, Sivil Toplum Kuruluşları, akademisyenler, lojistik hizmet alan ve lojistik hizmet veren firma temsilcilerinden oluşan uzman grup ile paylaşılmıştır. Ölçütlerin ağırlıklandırılması sonucu ortaya çıkan bulguların tüm uzman grubun görüşleri ve beklentileri ile doğru orantılı olduğu belirlenmiştir. Ayrıca Kızılay, Afet ve Acil Durum Müdürlüğü, Yerel Yönetimler, Sivil Toplum Kuruluşları ve akademisyenler, sürdürülebilir afet depo yeri seçimi için en iyi alternatifin $\mathrm{A}_{2}$ olduğunu destekleyici görüşler öne sürmüşlerdir. Diğer paydaşlar olan 
lojistik hizmet alan ve lojistik hizmet veren grup ise $\mathrm{A}_{4}$ alternatifinin üstünlüklerini ifade etmiş ve bu alternatifin idealliğine vurgu yapmıştır. Aradaki bu farklılı̆̆ın, lojistik hizmet veren ve lojistik hizmet alan grup için maliyet unsurunun öneminden kaynaklandığı söylenebilir.

İlgili literatür tarandığında böyle bir çalışmaya rastlanmamıştır. Bu bakımdan çalışma afet lojistiği kapsamında çeşitli açılardan karşılaştırılmaya örnek nitelikte düşünülebilir. Bununla birlikte araştırmada uzman grup ile görüşülmüş ancak zamandan kaynaklı kısıtlar sebebi ile uzman sayısı artırılamamıştır. Çalışmaya ilişkin başka bir kısıt ise gerek uzman grubun görüşleri gerekse yapılan literatür taramasında sürdürülebilirlik temasına yönelik herhangi bir ölçüt setine rastlanılmamış olmasıdır.

Diğer taraftan, çalışma kapsamında elde edilen sonuçların uzman grup ile yapılan görüşmelerde karar vericilerin beklentilerini desteklediği belirlenmiştir. Ancak insan kararları, beklentileri ve yargıları tam kesin olarak sayısal bir biçimde ifade edilemediğinden ve belirsiz olmasından dolayı gerçek durumu modellemek hem çok zor hem de çok karmaşıktır. Bu olgudan yola çıkarak gelecek çalışmalar için, bulanık ÇÖKV yöntemlerinden faydalanılarak sonuçlar mukayese edilebilir.

\section{Teşekkür}

$\mathrm{Bu}$ makalenin yazım aşamasında herhangi bir kurum veya kuruluştan maddi destek alınmamıştır.

\section{Yazar Katkıları}

Mustafa ERGÜN: Çalışmanın literatür kısmını yazmış ve analizlere katkı yapmıştır.

Selçuk KORUCUK: Verileri toplamış ve analizini yapmıştır.

Salih MEMIŞ̧: Çalışmanın istatistiksel analizlerine katkı yapmıştır

\section{Çıkar Çatışması}

Yazarlar çıkar çatışması bildirmemişlerdir.

\section{Kaynaklar}

Abbasi, M. ve Nilsson, F. (2016). Developing environmentally sustainable logistics: Exploring themes and challenges from a logistics service providers' perspective. Transportation Research Part D: Transport and Environment, 46, 273-283.

Ashinaka, T., Kubo, M. ve Namatame, A. (2016). A decision-support tool for humanitarian logistics. Gen, M., Katai, O., McKay, B., Namatame, A., Sarker, R.A., Zhang, B.-T. (Editörler) In Intelligent and Evolutionary Systems (s.293-304). Springer, Cham, 293-304.

Awasti, A., Chauhan, S.S. ve Goyal, S.K. (2011). A multi-criteria decision making approach for location planning for urban distribution centers under uncertainty. Mathematical and Computer Modelling, 53, 98-109.

Aydın, H., Ayvaz, B. ve Küçükaşçı, E. Ş. (2017). Afet yönetiminde lojistik depo seçimi problemi: Maltepe ilçesi örneği. Journal of Yaşar University, 12, 1-13.

Balcik, B. ve Beamon, B. M. (2008). Facility location in humanitarian relief. International Journal of Logistics, 11(2), 101-121.

Barbarosoğlu, G., Özdamar, L. ve Cevik, A. (2002). An interactive approach for hierarchical analysis of helicopter logistics in disaster relief operations. European Journal of Operational Research, 140(1), 118-133.

Boltürk, E., Onar Çevik, S., Öztayşi, B. ve Kahraman, C. (2016). Multi-attribute warehouse location selection in humanitarian logistics using hesitant fuzzy AHP, International Journal of the Analytic Hierarchy Process, 8(2), 271-298.

Boonmee, C., Arimura, M. ve Asada, T. (2017). Facility location optimization model for emergency humanitarian logistics. International Journal of Disaster Risk Reduction, 24, 485-498. 
Chan F.T.S., Kumar, N. ve Choy, K. L. (2007). Decision making approach for the distribution centre location problem in an supply chain network using the fuzzy-based hierarchical concept. Journal of Engineering Manufacture, 221 (B), 725-739.

Chanta, S. ve Sangsawang, O. (2012). Shelter-site selection during flood disaster. Lecture Notes in Management Science, 4, 282-288.

Christopher, M. (2011). Logistics, the supply chain and competitive strategy. In Logistics and Supply Chain Management (4. Baskr.). Prentice Hall. London, Pearson Education.

Davis, L. B., Samanlıoglu, F., Qu, X. ve Root, S. (2013). Inventory planning and coordination in disaster relief efforts. International Journal of Production Economics, 141(2), 561-573.

Demirdöğen, O., Erdal, H., Yazıcılar, F. ve Aykol, S. (2017). Disaster logistics facility location problem: An application for TR Al region. The International New Issues in Social Sciences, 5(5), 323-342.

Dubey, R. ve Gunasekaran, A. (2016). The sustainable humanitarian supply chain design: Agility, adaptability and alignment. International Journal of Logistics Research and Applications, 19(1), 62-82.

Dwyer, A., Zoppou, C., Nielsen, O., Day, S. ve Roberts, S. (2004). Quantifying social vulnerability: A methodology for identifying those at risk to natural hazards. Canberra: Geoscience Australia.

Eleren, A. (2006). Kuruluş yeri seçiminin analitik hiyerarşi süreci yöntemi ile belirlenmesi; Deri sektörü örneği. Atatürk Üniversitesi İktisadi ve İdari Bilimler Dergisi, 20 (2), 405-416.

Flanagan, B. E., Gregory, E. W., Hallisey, E. J., Heitgerd, J. L. ve Lewis, B. (2011). A social vulnerability index for disaster management. Journal of Homeland Security and Emergency Management, 8(1), 122.

Florez, J. V., Lauras, M., Okongwu, U. ve Dupont, L. (2015). A decision support system for robust humanitarian facility location. Engineering Applications of Artificial Intelligence, 46, 326-335.

Hadiguna, R. A., Kamil, I., Delati, A. ve Reed, R. (2014). Implementing a web-based decision support system for disaster logistics: A case study of an evacuation location assessment for Indonesia. International Journal of Disaster Risk Reduction, 9, 38-47.

Hale, T. ve Moberg, C. R. (2005). Improving supply chain disaster preparedness: A decision process for secure site location. International Journal of Physical Distribution ve Logistics Management, 35(3), 195-207.

Handayani, N. U., Rinawati, D. I. ve Wiguna, Y. K. (2015). Model of pre-positioning warehouse logistics for disaster eruption of Mount Merapi in Sleman Yogyakarta. In Proceedings of the Joint International Conference on Electric Vehicular Technology and Industrial, Mechanical, Electrical and Chemical Engineering (ICEVT \& IMECE) (pp. 401-405). IEEE.

Iqbal, S., Sardar, M. U., Lodhi, F. K. ve Hasan, O. (2018). Statistical model checking of relief supply location and distribution in natural disaster management. International Journal of Disaster Risk Reduction, 31, 1043-1053.

Ishizaka, A. ve Nemery, P. (2013). Multi-criteria decision analysis: methods and software, John Wiley \& Sons Ltd. Published, Chichester/UK.

Janic, M. ve Reggiani, A. (2002). An application of the multiple criteria decision making ( $m c d m$ ) analysis to the selection of a new hub airport. European Journal of Transport and Infrastructure Research, 2(2), 113-141.

Kim, S. K. ve Song, O. (2009). A maut approach for selecting a dismantling scenario for the thermal column in krr-1. Annals of Nuclear Energy, 36(2), 145-150.

Kobu, B. (2008). Üretim yönetimi, genişletilmiş güncellenmiş 14.baskı, Beta Basım Yayım, İstanbul.

Konuşkan, Ö. ve Uygun, Ö. (2014). Çok nitelikli karar verme (maut) yöntemi ve bir uygulaması, ISITES 2014, 1403-1412. 
Kovács, G. ve Spens, K. M. (2007). Humanitarian logistics in disaster relief operations. International Journal of Physical Distribution ve Logistics Management, 37(2), 99-114.

Kuo, M. S. ve Liang, G. S. (2011). Combining vikor with gra techniques to evaluate service quality of airports under fuzzy environment. Expert Systems with Applications, 38(3), 1304-1312.

Kusumastuti, R. D., Wibowo, S. S. ve Insanita, R. (2013). Modeling facility locations for relief logistics in Indonesia. In Humanitarian and Relief Logistics (pp. 183-205). Springer, New York, NY.

Lee, D. H., Dong, M. ve Bian, W. (2010). The design of sustainable logistics network under uncertainty. International Journal of Production Economics, 128(1), 159-166.

Liu, C., Chen, Z. H. ve Gong, Y. Y. (2013). Site selection of emergency material warehouse under fuzzy environment. Journal of Central South University, 20(6), 1610-1615.

Loken E. ve Botterud A. (2007). Planning of mixed local energy distribution systems: A comparison of two multi-criteria decision methods, 28thAnnual IAEE International Conference, Taipei, Taiwan, 15861587.

Loree, N. ve Aros-Vera, F. (2018). Points of distribution location and inventory management model for postdisaster humanitarian logistics. Transportation Research Part E: Logistics and Transportation Review, 116, 1-24.

Maharjan, R. ve Hanaoka, S. (2017). Warehouse location determination for humanitarian relief distribution in Nepal. Transportation Research Procedia, 25, 1151-1163.

Mete, H. O. ve Zabinsky, Z. B. (2010). Stochastic optimization of medical supply location and distribution in disaster management. International Journal of Production Economics, 126(1), 76-84.

Neto, J. Q. F., Bloemhof-Ruwaard, J. M., Van Nunen, J. A. ve Van Heck, E. (2008). Designing and evaluating sustainable logistics networks. International Journal of Production Economics, 111(2), 195-208.

O'brien, G., O'keefe, P., Rose, J. ve Wisner, B. (2006). Climate change and disaster management. Disasters, 30(1), 64-80.

Ofluoglu, A., Baki, B. ve Ar, İ. M. (2017). Multi-criteria decision analysis model for warehouse location in disaster logistics. Journal of Management Marketing and Logistics, 4(2), 89-106.

Özdamar, L. ve Demir, O. (2012). A hierarchical clustering and routing procedure for large scale disaster relief logistics planning. Transportation Research Part E: Logistics and Transportation Review, 48(3), 591-602.

Özdamar, L., Ekinci, E. ve Küçükyazıc1, B. (2004). Emergency logistics planning in natural disasters. Annals of Operations Research, 129(1-4), 217-245.

Peker, İ., Korucuk, S., Ulutaş, Ş., Okatan Sayın, B. ve Yaşar, F., (2016). Afet lojistiği kapsamında en uygun dağıtım merkez yerinin ahs-vikor bütünleşik yöntemi ile belirlenmesi: Erzincan ili örneği. Yönetim ve Ekonomi Araştırmaları Dergisi,14(1), 82-103.

Ramos, T. R. P., Gomes, M. I. ve Barbosa-Póvoa, A. P. (2014). Planning a sustainable reverse logistics system: Balancing costs with environmental and social concerns. Omega, 48, 60-74.

Rath, S. ve Gutjahr, W. J. (2014). A math-heuristic for the warehouse location-routing problem in disaster relief. Computers \& Operations Research, 42, 25-39.

Rodríguez-Espíndola, O., Albores, P. ve Brewster, C. (2018). Disaster preparedness in humanitarian logistics: A collaborative approach for resource management in floods. European Journal of Operational Research, 264(3), 978-993.

Roh, S. Y., Jang, H. M. ve Han, C. H. (2013). Warehouse location decision factors in humanitarian relief logistics. The Asian Journal of Shipping and Logistics, 29(1), 103-120.

Roh, S., Pettit, S., Harris, I. ve Beresford, A. (2015). The pre-positioning of warehouses at regional and local levels for a humanitarian relief organisation. International Journal of Production Economics, 170, 616-628. 
Saaty, T. L. (2008). Decision making with the analytic hierarchy process. International Journal of Services Sciences, 1 (1), 83-98.

Saaty, T. L., ve Niemira, M. P. (2006). A framework for making a better decision. Research Review, 13(1), $1-4$.

Salam, M. A. (2006). Disaster logistics management, https://www.poms meetings.org/confpapers/005/0050009.doc, (12.01.2019).

Savitha, K. ve Chandrasekar, C. (2011). Trusted network selection using saw and topsis algorithms for heterogeneous wireless networks, International Journal of Computer Applications, 26(8), 22-29.

Schulz, S. F. ve Blecken, A. (2010). Horizontal cooperation in disaster relief logistics: benefits and impediments. International Journal of Physical Distribution \& Logistics Management, 40(8/9), 636-656.

Seraji, H., Tavakkoli-Moghaddam, R. ve Soltani, R. (2019). A two-stage mathematical model for evacuation planning and relief logistics in a response phase. Journal of Industrial and Systems Engineering, 12(1), 129-146.

Sheu, J. B. (2007). An emergency logistics distribution approach for quick response to urgent relief demand in disasters. Transportation Research Part E: Logistics and Transportation Review, 43(6), 687-709.

Şahin, S. (2017). Çok kriterli karar verme yöntemleri ile bulanık ortamda afet yönetimi sisteminde geçici barınma alanlart yer seçimi (Yayınlanmamış Yüksek Lisans Tezi, İstanbul Ticaret Üniversitesi).

Temiz, H. (2018). Afet yönetiminde lojistik depo seçimi ve bir uygulaması (Yayınlanmamış Yüksek Lisans Tezi, İstanbul Ticaret Üniversitesi).

Tunca, Z. Ömürbek N. Cömert G. ve Aksoy E. (2016). Opec ülkelerinin performanslarının çok kriterli karar verme yöntemlerinden entropi ve maut ile değerlendirilmesi. Süleyman Demirel Üniversitesi Vizyoner Dergisi, 7(14), 1-12.

Van Wassenhove, L. N. (2006). Humanitarian aid logistics: supply chain management in high gear. Journal of the Operational Research Society, 57(5), 475-489.

Wang, B. C., Li, M., Hu, Y., Huang, L. ve Lin, S. M. (2018). Optimizing locations and scales of emergency warehouses based on damage scenarios. Journal of the Operations Research Society of China, 1-20.

Xifeng, T., Ji, Z. ve Peng, X. (2013). A multi-objective optimization model for sustainable logistics facility location. Transportation Research Part D: Transport and Environment, 22, 45-48.

Yang, H., Yang, L. ve Yang, S. (2011). Hybrid zigbee rfid sensor network for humanitarian logistics centre management, Journal of Network and Computer Applications, (34), 938-948.

Yeh, C. H. (2003). The selection of multi-attribute decision making methods for scholarship student selection,International Journal of Selection and Assessment, 11(4), 289-296.

Zadeh, L.A. (1965). Fuzzy sets. Information and Control, 8, 338-353. 
EK: 1. Ölçütler açısından karar matrisi, ağırlıklar ile tutarlılık

\begin{tabular}{cccccc}
\hline \multirow{2}{*}{ Ölçütler } & \multicolumn{3}{c}{ Karar Matrisi } & Ağırlıklar (W) & Tutarlılık Oranı (CR) \\
\cline { 2 - 5 } & $\mathrm{K}_{1}$ & $\mathrm{~K}_{2}$ & $\mathrm{~K}_{3}$ & & \\
\hline $\mathrm{K}_{1}$ & 1 & 7 & 6 & 0,067 & $0,095<0,010$ \\
\hline $\mathrm{K}_{2}$ & $1 / 7$ & 1 & 3 & 0,640 & \\
\hline $\mathrm{K}_{3}$ & $1 / 6$ & $1 / 3$ & 1 & 0,293 & \\
\hline
\end{tabular}

EK: 2. Konum ana ölçütüne ait alt ölçütler açısından karar matrisi, ağırlıklar ve tutarlılık

\begin{tabular}{|c|c|c|c|c|c|c|c|c|c|c|}
\hline \multirow{2}{*}{$\begin{array}{l}\text { Alt } \\
\text { Ölçüt }\end{array}$} & \multicolumn{7}{|c|}{ Karar Matrisi } & \multirow{2}{*}{$\begin{array}{l}\text { Ağırlıklar } \\
\text { (W) }\end{array}$} & \multirow{2}{*}{$\begin{array}{l}\text { Tutarlılık } \\
\text { (CR) }\end{array}$} & \multirow[t]{2}{*}{ Oranı } \\
\hline & $\mathrm{K}_{11}$ & $\mathrm{~K}_{12}$ & $\mathrm{~K}_{13}$ & $\mathrm{~K}_{14}$ & $\mathrm{~K}_{15}$ & $\mathrm{~K}_{16}$ & $\mathrm{~K}_{17}$ & & & \\
\hline $\mathrm{K}_{11}$ & 1 & 4 & 3 & 3 & 5 & 6 & 7 & 0,330 & \multirow{7}{*}{\multicolumn{2}{|c|}{$0,092<0,010$}} \\
\hline $\mathrm{K}_{12}$ & $1 / 4$ & 1 & $1 / 7$ & 3 & 3 & 4 & 4 & 0,161 & & \\
\hline $\mathrm{K}_{13}$ & $1 / 3$ & 7 & 1 & 4 & 4 & 4 & 5 & 0,276 & & \\
\hline $\mathrm{K}_{14}$ & $1 / 3$ & $1 / 3$ & $1 / 4$ & 1 & 3 & 3 & 3 & 0,096 & & \\
\hline $\mathrm{K}_{15}$ & $1 / 5$ & $1 / 3$ & $1 / 4$ & $1 / 3$ & 1 & 2 & 2 & 0,054 & & \\
\hline $\mathrm{K}_{16}$ & $1 / 6$ & $1 / 4$ & $1 / 4$ & $1 / 3$ & $1 / 2$ & 1 & 2 & 0,043 & & \\
\hline $\mathrm{K}_{17}$ & $1 / 7$ & $1 / 4$ & $1 / 5$ & $1 / 3$ & $1 / 2$ & $1 / 2$ & 1 & 0,040 & & \\
\hline
\end{tabular}

EK: 3. Altyapı ana ölçütüne ait alt ölçütler açısından karar matrisi, ağırlıklar ve tutarlılık

\begin{tabular}{|c|c|c|c|c|c|c|c|c|c|}
\hline \multirow{2}{*}{$\begin{array}{l}\text { Alt } \\
\text { Ölçüt }\end{array}$} & \multicolumn{6}{|c|}{ Karar Matrisi } & \multirow{2}{*}{$\begin{array}{l}\text { Ağırlıklar } \\
(\mathrm{W})\end{array}$} & \multirow{2}{*}{$(\mathrm{CR})$} & \multirow[t]{2}{*}{ Tutarlılık Oranı } \\
\hline & $\mathrm{K}_{21}$ & $\mathrm{~K}_{22}$ & $\mathrm{~K}_{23}$ & $\mathrm{~K}_{24}$ & $\mathrm{~K}_{25}$ & $\mathrm{~K}_{26}$ & & & \\
\hline $\mathrm{K}_{21}$ & 1 & 3 & 6 & 3 & 3 & 3 & 0,362 & & \multirow{6}{*}{$0,098<0,010$} \\
\hline $\mathrm{K}_{22}$ & $1 / 3$ & 1 & 3 & 3 & 3 & 3 & 0,236 & & \\
\hline $\mathrm{K}_{23}$ & $1 / 6$ & $1 / 3$ & 1 & $1 / 5$ & $1 / 3$ & $1 / 5$ & 0,040 & & \\
\hline $\mathrm{K}_{24}$ & $1 / 3$ & $1 / 3$ & 5 & 1 & 3 & 3 & 0,173 & & \\
\hline $\mathrm{K}_{25}$ & $1 / 3$ & $1 / 3$ & 3 & $1 / 3$ & 1 & 2 & 0,099 & & \\
\hline $\mathrm{K}_{26}$ & $1 / 3$ & $1 / 3$ & 5 & $1 / 3$ & $1 / 2$ & 1 & 0,090 & & \\
\hline
\end{tabular}


EK: 4. İş Birliği ana ölçütüne ait alt ölçütler açısından karar matrisi, ağırlıklar ve tutarlılık

\begin{tabular}{lcccccc}
\hline \multirow{2}{*}{$\begin{array}{l}\text { Alt } \\
\text { Ölçüt }\end{array}$} & \multicolumn{3}{c}{ Karar Matrisi } & \multicolumn{2}{c}{ Ağırlılar } & Tutarlılı Oranı (CR) \\
\cline { 2 - 5 } & $\mathrm{K}_{31}$ & $\mathrm{~K}_{32}$ & $\mathrm{~K}_{33}$ & $\mathrm{~K}_{34}$ & $(\mathrm{~W})$ & \\
\hline $\mathrm{K}_{31}$ & 1 & $1 / 7$ & $1 / 7$ & $1 / 5$ & 0,044 \\
\hline $\mathrm{K}_{32}$ & 7 & 1 & 5 & 3 & 0,553 & $0,090<0,010$ \\
\hline $\mathrm{K}_{33}$ & 7 & $1 / 3$ & 1 & 3 & 0,273 & \\
\hline $\mathrm{K}_{34}$ & 5 & $1 / 5$ & $1 / 3$ & 1 & 0,130 & \\
\hline
\end{tabular}

EK: 5. MAUT yöntemi için karar matrisi ve en iyi ve en kötü değerler

\begin{tabular}{llll}
\hline Alternatifler & $\mathrm{K}_{1}$ & $\mathrm{~K}_{2}$ & $\mathrm{~K}_{3}$ \\
\hline $\mathrm{A}_{1}$ & 2 & 3 & 4 \\
\hline $\mathrm{A}_{2}$ & 4 & 5 & 4 \\
\hline $\mathrm{A}_{3}$ & 5 & 3 & 2 \\
\hline $\mathrm{A}_{4}$ & 3 & 4 & 2 \\
\hline $\mathrm{A}_{5}$ & 5 & 4 & 2 \\
\hline En İyi Değer & 5 & 5 & 4 \\
\hline En Kötü Değer & 2 & 3 & 2 \\
\hline
\end{tabular}

EK: 6. MAUT yöntemi için normalize edilmiş karar matrisi

\begin{tabular}{llll}
\hline Alternatifler & $\mathrm{K}_{1}$ & $\mathrm{~K}_{2}$ & $\mathrm{~K}_{3}$ \\
\hline $\mathrm{A}_{1}$ & 0 & 0 & 1 \\
\hline $\mathrm{A}_{2}$ & 0,667 & 1 & 1 \\
\hline $\mathrm{A}_{3}$ & 1 & 0 & 0 \\
\hline $\mathrm{A}_{4}$ & 0,333 & 0,500 & 0 \\
\hline $\mathrm{A}_{5}$ & 1 & 0,500 & 0
\end{tabular}


EK: 7. MAUT yöntemi için ağırlıklandırılmış normalize karar matrisi

\begin{tabular}{llll}
\hline Alternatifler & $\mathrm{K}_{1}$ & $\mathrm{~K}_{2}$ & $\mathrm{~K}_{3}$ \\
\hline $\mathrm{A}_{1}$ & 0 & 0 & 0,293 \\
\hline $\mathrm{A}_{2}$ & 0,045 & 0,640 & 0,293 \\
\hline $\mathrm{A}_{3}$ & 0,067 & 0 & 0 \\
\hline $\mathrm{A}_{4}$ & 0,022 & 0,320 & 0 \\
\hline $\mathrm{A}_{5}$ & 0,067 & 0,320 & 0 \\
\hline
\end{tabular}

EK: 8. SAW yöntemi için karar matrisi ve makmin $r-r_{j}$ değerleri

\begin{tabular}{llllllll}
\hline & $\begin{array}{l}\text { Ölçüt } \\
\text { Türleri }\end{array}$ & $\mathbf{A}_{\mathbf{1}}$ & $\mathbf{A}_{\mathbf{2}}$ & $\mathbf{A}_{\mathbf{3}}$ & $\mathbf{A}_{\mathbf{4}}$ & $\mathbf{A}_{\mathbf{5}}$ & $\begin{array}{l}\text { Makmin } \\
\mathbf{r}-\mathbf{R}_{\mathbf{j}}\end{array}$ \\
\hline $\mathbf{K}_{\mathbf{1}}$ & Min. & 3 & 3 & 3 & 4 & 2 & 2 \\
\hline $\mathbf{K}_{\mathbf{2}}$ & Mak. & 4 & 5 & 2 & 4 & 3 & 5 \\
\hline $\mathbf{K}_{\mathbf{3}}$ & Mak. & 1 & 2 & 1 & 2 & 1 & 2 \\
\hline
\end{tabular}

EK:9. SAW yöntemi için normalize edilmiş karar matrisi

\begin{tabular}{lllllll}
\hline & $\begin{array}{l}\text { Ölçüt } \\
\text { Türleri }\end{array}$ & $\mathbf{A}_{\mathbf{1}}$ & $\mathbf{A}_{\mathbf{2}}$ & $\mathbf{A}_{\mathbf{3}}$ & $\mathbf{A}_{\mathbf{4}}$ & $\mathbf{A}_{\mathbf{5}}$ \\
\hline $\mathbf{K}_{\mathbf{1}}$ & Min. & 0,667 & 0,067 & 0,067 & 0,500 & 1 \\
\hline $\mathbf{K}_{\mathbf{2}}$ & Mak. & 0,800 & 1 & 0,400 & 0,800 & 0,600 \\
\hline $\mathbf{K}_{\mathbf{3}}$ & Mak. & 0,500 & 1 & 0,500 & 1 & 0,500 \\
\hline
\end{tabular}

EK: 10. SAW yöntemi için ağırlıklandırılmış normalize karar matrisi

\begin{tabular}{llllll}
\hline & $\mathbf{A}_{\mathbf{1}}$ & $\mathbf{A}_{\mathbf{2}}$ & $\mathbf{A}_{\mathbf{3}}$ & $\mathbf{A}_{\mathbf{4}}$ & $\mathbf{A}_{\mathbf{5}}$ \\
\hline $\mathbf{K}_{\mathbf{1}}$ & 0,045 & 0,045 & 0,045 & 0,034 & 0,067 \\
\hline $\mathbf{K}_{\mathbf{2}}$ & 0,512 & 0,640 & 0,256 & 0,512 & 0384 \\
\hline $\mathbf{K}_{\mathbf{3}}$ & 0,147 & 0,293 & 0,147 & 0,293 & 0,147 \\
\hline
\end{tabular}

